\title{
Enhancing Competency in English: The Covert Approach a Complementary to the Overt Approach in Teaching Grammar
}

\author{
Hussein Islam Abdullah (Corresponding author) \\ Faculty of Education, National University of Malaysia (UKM) \\ 43600 UKM Bangi, Selangor Darul Ehsan, Malaysia \\ E-mail: Hussein07@live.com.my \\ Parilah Mohd Shah \\ Faculty of Education, National University of Malaysia (UKM) \\ 43600 UKM Bangi, Selangor Darul Ehsan, Malaysia \\ E-mail: drparila@gmail.com
}

Received: 08-07-2014

Accepted: 06-09-2014

Published: 01-01-2015

doi:10.7575/aiac.ijalel.v.4n.1p.191

URL: http://dx.doi.org/10.7575/aiac.ijalel.v.4n.1p.191

\begin{abstract}
Over the years, there has been a decline in the competency of the English Language in Malaysian schools. Many parties among them the Ministry of Education, relevant NGOs, academicians and people have expressed concern over the matter. The Education Ministry through its transformational policy has taken several measures to overcome the matter. It is employing appropriate strategies to solve the problems. The focus is on learning and teaching strategies as well as the content of the language. There is no doubt that grammar is a very important component in acquiring the language in primary and secondary schools. The English teachers mostly use the communicative approach in teaching grammar. This is in line with the KBSR syllabus in mid 1980s which emphasized on the communicative method. Teachers' training and materials such as textbooks cater for the covert method. However, some tend to ignore the structural approach which is equally effective and meaningful to increase the level of the students' proficiency which was popular in the 1960s. The paper discusses on the two different approaches used - the covert and overt approaches - their strengths as well as weaknesses. Application of both approaches is also taken into consideration giving a better view of how grammar should be taught in schools.
\end{abstract}

Keywords: Competency in English, teaching grammar, covert approach, overt approach

\section{Introduction}

\subsection{Importance of English}

English is a very important language in the world. It has moved a step from being an international language to a global language. It is a widely spoken language because of its status as a political and economical language of the world. Krishnan (2012) said that this is evident today when international business deals and political diplomacy are carried out in the language. Globalization has placed English to a very important position in Malaysia's education. The Ministry of Education of lately has put tremendous effort to revive the proficiency in English among the students. This is due to a consistent decrease over the years in the level of proficiency among the students especially in the skills of speaking as well as writing - two important output skills.

\subsection{Initiatives to upgrade English}

As a result, the Ministry of Education has come up with different programmes to enhance the command of the language. These comes under the new policy - MBMMBI (upholding the status of the Malay Language and to strengthen the English Language) a replacement to the previous policy ETEMS (the teaching of Science and Mathematics in English) which was abolished in 2009. Studies found that the teaching of Science and Mathematics in English was problematic and did not improve students' proficiency in English as desired. Ha et.al (2013) Beginning of 2012, in a pilot project carried out in 2000 selected schools, the form 1 students sat for a diagnostic test and based on the results of the test they will be grouped according to their level of proficiency. This is known as the set system. The students will be taught according to their abilities based on the test. In addition, the ministry has introduced vocabulary lessons to the Form 1 students for the first 3 months to enhance their mastery in English words. The ministry has also made it compulsory for the 70,000 over English teachers to sit for the CPT (Cambridge Placement Test) in association with the University of Cambridge. Based on the results of the test, the teachers too are categorised into different levels of the Common European Framework of Reference for Languages (CEFR). These teachers are required to attend classes conducted by the ELTC (English Language Teaching Centre), British Council and other agencies for a year till they achieve the desired level. 
These are some of the measures taken to overcome the situation. While these measures were taken to address the situation, we cannot deny the fact that these are solutions which will have a moderate impact on the command of the English Language among the students. The heart of the problem which is teaching approach or pedagogy has not been given due focus and attention.

\subsection{Beliefs in teaching Grammar}

In the 1960s and 1970s, grammar was taught directly by the English teachers from primary to secondary level under the structural method which worked perfectly well as supported by some scholars. Grammar has been a very important part of the teaching and learning process of the language. In the mid $80 \mathrm{~s}$, the curriculum has been changed whereby a communicative approach was introduced to teach the language with less emphasis on grammar. Over the years, we have seen a decline in the command of the language especially in speaking and writing which is very eminent in the beginning of the century. Krishnan (2012) For most of us, grammar is simply a way to understand how to communicate more clearly, effectively and most importantly correctly. The study of grammar allows us to analyse patterns and avoid making mistakes. In this way, it can lead to more accurate writing and speaking skills among the students. There are teachers who prefer to use the structural method in teaching their students thinking that this method is the best to enhance the proficiency in the language. On the other hand, there are also some teachers who prefer to use the communicative method in teaching grammar to their students. Their belief is teaching grammar should be done in a communicative manner whereby the students will grasp the parts of speech without going through the tiring and boring way of learning the language.

Different beliefs' in teaching grammar indeed play a very important part among the teachers. Hence, throughout the teaching of grammar, teachers have witnessed the implementation of these two methods - the structural method (overt approach) usually connected with the old grammarians and the communicative method (covert approach) which was gaining popularity in the $70 \mathrm{~s}$ especially in Asian countries. Malaysia can be considered as a frontrunner in implementing the approach in the early 70 s but it took many years before it really started to have an impact. Thus, the purpose of this paper is to explore the differences between the overt and covert approaches in teaching, identify the strengths and weaknesses in both approaches used in schools and will suggest recommendations of ways to complement both approaches. The paper also tries to advocate that all teachers learn to utilise and to appreciate both overt as well as covert approaches in their teaching. This conceptual paper is significant because it will explore advantages and disadvantages behind the application of covert and overt approaches in classroom teaching that affects the proficiency of the students in the English Language. It will examine those reasons and make recommendations for future empirical research.

\section{Literature Review}

\subsection{Definition of Grammar}

Historically, the word grammar comes from a Greek root, the word graphein, which means to write or to draw. Early forms of grammar can be traced back to ancient Greece, and even further back to $4^{\text {th }}$ century BC India. According to American linguist Fromkin et. al. (2011), their definition of grammar is:

the knowledge speakers have about the units and rules of their language — rules for combining sounds into words - phonology, rules of word formation - morphology, rules for combining words into phrases and phrases into sentences - syntax, as well as the rules for assigning meaning - semantics.(p.13)

Grammar can also be defined as the structure of language, expressed through a set of specific linguistic rules, known as syntax. It defines the different parts of speech, such as words and sentences, and allows us to discuss how and why we communicate. Therefore, grammar represents rules in a language which needed to be followed to make sensible meanings.

\subsection{Teaching Grammar}

Byrd (1998) stated that learning grammar is important but it is not easy to make students understand the concept of grammar. People usually think that those who speak correct grammar are superior than those who do not, thus indirectly equating the prestige of a language to its grammar. So, it is important to learn the aspects of grammar not so much to attain prestige but rather for effective communication purpose. Byrd also states that teachers practise teaching grammar directly to students in the anticipation that they will be able to produce good output skills in terms of speaking and writing. While the method proves successful in classroom it cannot be said the same in the real life conversation. On the contrary, she also mentioned that some teachers prefer the covert approach in their teaching after learning about the contrast between language learning and acquisition.

Chitravelu et. al. (2005) explains that it is possible that someone who can produce perfectly correct sentences and communicate efficiently may not be able to explain the rules of grammar. This is true of many speakers of English, including some native speakers. Such people have implicit knowledge of grammar - they know grammar at the level of use. However, one still needs to have explicit knowledge of grammar to be able to describe and explain the rules.

Another factor to be considered is the appropriate age to teach grammar to the students. In this regard, Ellis (2006) gives his view: 
teaching grammar early is valuable because it provides a basis for the real learning that follows. This seems to echo Lightbrown's metaphor, according to which grammar instruction facilities learning by providing learners with "hooks" which they can grab on to. (p.90)

For the past 35 years, many theories, ideas and wisdom had been suggested which in some way or the other changed people perspective towards the teaching of grammar particularly to L2 learners. Batstone (1995) in his article stated that there are three approaches to teaching grammar and explains them as following:

- Teaching grammar as product - helps learner to notice and to structure by focusing on specified forms and meanings

- Teaching grammar as process: gives learners practice in the skills of language use, allowing them to systematically utilise their knowledge

- Teaching grammar as skill: carefully guides learners to use grammar for their own communication (p.73)

\section{Theoretical Framework}

\subsection{Krashen's Input Hypothesis-Monitor model}

There are numerous theories which discuss the subject in depth. Stephen Krashen, who specializes in theories of language acquisition and development, has researched the area of non English and bilingual language acquisition. In what he originally called the input hypothesis which he introduced in 1985, Krashen claims that humans acquire language only through comprehensible input. Krashen points out that to acquire a language we do not have to master the grammar rules. The statement above shows that using the covert approach which is also known as the communicative method is good enough to acquire the second language. The students only need to be in a setting where meaningful conversation takes place. Krashen is less concerned about the forms but focuses more on the meaning that takes place. Krashen, however, stressed that grammar can still be taught to those students who are willing and interested to learn. Teachers must use the language as a tool of communication instead of using L1. Both parties must be convinced that learning and teaching grammar is the core to acquiring the second language. The teachers and students play important roles in acquiring the second language willingly without force or boredom. It shows that combinations of both approaches are important in acquiring good proficiency level in the language. Krashen is very careful in saying that the competencies of the teachers as well as the willingness of the students are very important factors when learning grammar.

\subsection{Communicative Competence Model}

Communicative competence model introduced by Hymes in 1966 is a linguistic term that shows the speakers' knowledge of different parts of a language which include the sound system, structure of words and word order. It also depicts the ability the speaker has on when and how to apply the words appropriately when communicating in a social circle. The model itself supports whole-heartedly the combination of both approaches. The communicative competence model acknowledges the overt method in acquiring a language. In this model, grammar is taught to ensure that the language user is able to initiate a conversation entirely in the language effectively. However, the parts of speech taught are simple and relevant to everyday communication. This is known as the linguistic competence a branch under the communicative competence. Hymes came up with the idea of proposing the communicative competence model after observing that Chomsky's 1965 explanation on the differences between competence and performance is not very satisfactory. To do this, he undertook an ethnographic study to explore the communicative competence which is now accepted as the communication ethnography. Language scholars believed that Hymes' communicative competence model is better compared to Chomsky's linguistic competence in terms of second and foreign language teaching literature. It shows that Chomsky's overt approach through his linguistic competence alone is not good enough.

\subsection{Theory of Noticing (The noticing hypotheses)}

The theory of noticing pioneered by Schmidt in 1990 discusses the connection between overt and covert knowledge regarding the approaches in teaching grammar. The structural method or explicit knowledge refers to learning grammar knowingly through formal settings in school. In other words, the students should notice what they are learning before they can apply it. The theory of noticing is emphasizing more on the overt approach as the most important rule in learning a language well. By learning the grammar overtly, he will be able to speak the language accurately without making any mistakes because he would have notice the important parts compared to learning covertly.

\section{The Overt and Covert Approaches}

\subsection{Approaches in Teaching Grammar}

What is the definition of an approach or method in language teaching? Beare (2013) stated that it should be teaching style, procedure or way which brings out the best practice and results in language teaching. If a teacher applies this known approach it will definitely be effective in his teaching compared to different and outdated ways which do not show results. Beare also pointed out that the best approaches or methods will lead to quality of language teaching.

The different teaching approaches and methods that have emerged in the last 80 years, while often have very different characteristics in terms of goals, assumptions about how a second language is learned and preferred teaching technique, have in common the perception that changes in teaching methodology will lead to improvement to language learning. 
This notion has been reinforced by professional organizations that endorse particular teaching approaches and methods, by academics who support some and reject others, by publishers who produce and sell textbooks based on the latest teaching approaches and methods and by teachers who are constantly looking for the best method of teaching a language. Beare (2013)The writer agrees there are numerous approaches in teaching grammar but would like to emphasize on two main, basic and classic approaches which acts as an umbrella to the other approaches or methods. They are the covert and overt approaches which are also known as the structural and communicative methods respectively. The writer would also like to share that both approaches have their strengths and weaknesses but the beauty of it is that they can complement each other.

\subsection{The Overt Approach (Structural Method)}

The overt approach is teaching the rules of grammar to the students as it is. It is a process of dividing the whole parts of speech into manageable bite size chunks and then introduces these to the students, one chunk per lesson, so that they gradually and systematically accumulate a complete picture of the language. The grammar rules are explained explicitly by the teacher when presenting it. There are two options when applying the overt approach in the classroom. They are the deductive approach and inductive approach which is also known as the discovery method. In the deductive approach, the teacher presents the rule/pattern/generalization and then goes to provide practice in the application of those rules. When a teacher is explaining rules of grammar to his students, this approach is popularly known as the top down approach. In this approach, the teacher explains the rules of grammar explicitly to the students. On the contrary, the bottom up approach is when students are given a number of exercises and they try by themselves with the guidance of the teachers to find the connection or rule governing those particular parts of speech. For example exercises relating to subject verb agreement will enable the students to come to the conclusion and apply that conclusion to answer the following questions. This is because they have noticed the pattern. This is also known as the inductive approach.

In this approach, the teachers need a methodology that finds ways to present small pieces of language that have previously been selected by the teacher to exemplify particular structures. Each new item will then be practised until the students are familiar with it, revised at future dates and eventually incorporated into the larger body of language that has previously been presented and practised. This is known as presentation, practice and production.

\subsection{The Covert Approach (Communicative Method)}

Chung (2005) mentioned that the origin of the (Communicative Language Teaching) CLT can be traced back in the West in the early 60 s and subsequently spread to other Eastern countries within the time span of 20 years. Over the years, because of its popularity, the CLT has become the basis of English Language Syllabus for many countries including Malaysia. Chung also stated that "In Malaysia, CLT was adopted as early as the 1970s..." but the implementation only began in mid 80s.In the covert approach, the teacher gets the people involved in using the structure without drawing the attention to grammatical rules. The students' attention is focused on the activity and not the grammar rules but they have ample opportunity to practise the question forms because in covert approach, communicative learning is given priority. The approach creates an environment where a lot of language, known and unknown is met, mainly when doing speaking and listening tasks and where the students are helped with new language only when they already have some awareness of it and have curiosity or questions about it.

\section{Reasons on the Choice of the Overt Approach}

\subsection{No Study Confirms the Effectiveness of Communicative Classrooms}

No actual empirical studies prove that 'communicative' classrooms produce better language learners than the more traditional teacher dominated classrooms. In the beginning, a small number of evidence supports it because of its feel good features and promising results. However, research on communicative approach has also shown strong evidence which shows that, it can also cause inability among the students to master the appropriate parts of the speech and this will lead to slowdown in progress in acquiring the second language.

\subsection{Inability to Answer Examination Questions}

Let us now turn to a very practical argument in favour of teaching grammar. Students in Malaysia are required to do well in the infamous UPSR examination for Year 6 pupils and SPM examination for Form 5 students. Therefore, to give these students an incomplete grounding in grammar, regardless of one's conviction about teaching it covertly, is to do them a great disservice. Pupils have to know and apply the rules of English grammar in order to do well on such exams. Grammar is a very important aspect especially in writing. Fortunately, PMR examinations for the Form 3 students had been abolished in 2013.

\subsection{Based on Functional Grammar - Text, System and Linguistics Structure}

Approaching grammar using the overt method is a way to introduction of functional grammar because the conceptual framework on which it is based is a functional one rather than a formal one. It is functional in three distinct although closely related senses; in its interpretation of text, system and elements of linguistics structures.

Chung said that "Communication proficiency will become easier to achieve only when one has grasped the necessary knowledge of language such as grammar.” (p.35). Another researcher Pawlak (2004) wrote: 
with time, however, it turned out that the complete rejection of formal instruction (overt approach) might have been premature and in the 1990s, grammar was rehabilitated and recognized once again as an essential component of language learning. (p.271-272)

Mareva (2012) pointed out "that emphasis on linguistic competence and accuracy as production is expected to be error free if this approach is used." (p105)

\subsection{Rules of Grammar must be Taught, it's not a Natural Process}

There is no doubt that there are cases where learners acquire the second language grammar on their own naturally. They picked it up easily by deliberately getting themselves close to the native speakers and communicating in the language. For example, people who migrated from Japan, China, Spain and other places to US are able to acquire the language on their own within certain period of time. This happens rather quickly with the young immigrants. However, the same cannot be said of other learners. If we study carefully, we will find out that there are groups who have achieved a certain competency in the language but their English is not accurate. Pienemann (1984) has shown effectively in his research that learners who are given grammar lesson achieved a certain degree of proficiency and progressed to the next level within two weeks compared to those without any exposure to grammar classes will normally take a few months.

Pawlak (2004) stated that:

"one most compelling arguments against purely communicative approaches is that learners often fail to achieve high levels of grammatical competence even if they learn the language naturally or have plentiful inclass exposure to comprehensible input as well as opportunities for meaningful language use." (p. 272)

\subsection{Viewpoints from Other Language Scholars}

Ellis (2006) stated that "although there is no convincing direct and indirect evidence to support the teaching of grammar however, many studies... can be expected to favour grammar teaching." (p.86).He also mentioned that in order to reap the maximum benefit from the teaching of grammar, studies have shown that the effective grammar must be taught in line with the learners' natural processes of acquisition. He also pointed out that grammar should be taught at a very young age to enable the learners to grasp the basic rules of grammar and build upon it subsequent understanding.

Richards et.al. (2001) felt that although many stated they followed a communicative approach to teaching, "many of the respondents in a research still hold firmly to the belief that grammar is central to language learning and direct grammar teaching is needed by their ESL students." (p.54)

\section{Reasons on the Choice of Covert Approach}

\subsection{Learning Materials and Activities Incorporate the Communicative Language Teaching}

Since the introduction of the CLT in Malaysian schools, most of the textbooks and authentic materials have been written to incorporate communicative activities. Chung (2004). So, teachers have abundant exercises and activities to conduct in the classrooms using the covert approach. Richards et al (1995) stressed that the communicative language teaching touches on real life situation like giving directions, conversation, problem solving, dialogues and etc which bring benefits to the learners. Furthermore, these activities will instill a sense of cooperation, togetherness and teamwork which indirectly create a sense of language being used naturally. (Brumfit,1984)

\subsection{Learning without Feeling Anxious}

When learning process takes place especially during games, role-plays and drama, the language is being practised unconsciously. They communicate and converse freely among themselves without being tied to a certain rule or placed in a boundary. These exciting activities create an atmosphere where the students practise the focused language unconsciously. On top of that, they are playing and enjoying doing it.

\subsection{Viewpoints on SLA Acquisition}

Pawlak (2004) stated that majority of language experts preferred CLT to be used in acquiring the second language. This is because since 1970s, the linguist had some reservations about the old traditional method which in their perspective did not contribute to language learning and is against the natural processes of acquiring a language. Furthermore, from the viewpoint of Krashen, grammar has no significant part in learning a new language although he is not entirely objecting to the idea. Even if a learner has the knowledge of grammar rules, he may not be able to converse in the language overnight. Besides the knowledge of knowing grammar rules will not last long.

\subsection{Structural Method is Ineffective and Boring}

Babic (2010) said that in a research conducted on tertiary students, all of them connected grammar only to grammatical exercises done during their classes and 65 percent of them stated they thought that grammar was not important for knowing the language, because the only thing that was truly important was communication and meaning being conveyed to the other person. 


\section{Teachers' Beliefs in Teaching Grammar}

Many studies have been carried out to analyse whether teachers' beliefs and perceptions on teaching grammar play an important part in their classroom practices. One such study by Farrel et al (2005) showed that teachers are tied to their beliefs when they are teaching grammar in the classroom. For example, teacher A prepared a lesson based on the communicative method and when she entered the classroom the lesson was conducted in communicative method. The same applies to teacher B who prepared a lesson based on structural method and taught her class in a method which she believed in. Teacher A and B who have 10 and 24 years of experience respectively are contrast in their approaches. This could be due to their learning experience in school as well as the training they received in teacher's training college.

However, it must be noted that there are cases where the teachers' preparation for lessons are the opposite of their classrooms' activities. They may prepare covert approach but once they entered the class they will switch to teaching using the overt method. This is in sharp contrast of what they have learnt in college and the curriculum of the language. They believed that what they have learnt in school is a better approach and indirectly influenced by their former teachers' style of teaching.

\section{Recommendations}

Based on the facts stated, learning grammar is a very important part of language learning and language acquisition. We cannot deny that grammar is the heart of a language. In order to achieve this, grammar should be introduced to primary level as early as possible because at this age, they have the tendency and motivation to grasp the rules quickly and apply it in their writing as well as speaking, two most important skills. However, it should be simplified and made fun to bring the enthusiasm in learning and teaching the subject which many perceived as a irrelevant. Simple, relevant and often used parts of speech will not do harm on the students. At the secondary level, grammar should be taught to suit different level of proficiency. However, focus should be given to basic grammar which is used in everyday life. If possible, a repetition of the same parts of speech in primary school can be taught but with higher level of difficulties. Nonetheless, we can only teach them if they are prepared to learn. There should be no force in learning grammar; otherwise it will put a stop in acquiring the second language. We also have to remember that learners acquire language at their own pace

Lastly, many research have been carried out in many parts of the world with the results sometimes leaning towards overt approach as the best method to teach grammar and at times covert approach prevails as the best way. It is not wrong to use both ways to teach grammar. The bottom line is the learners are able to acquire their second language and used it correctly.

\section{Conclusion}

As a conclusion, Gardner (2008) summed it up perfectly by stating that

in many parts of the world, English Language teachers have changed, or are changing, from a traditional approach to teaching formal grammar rules to a more communicative meaningfully in context. Interestingly, in some countries there is change towards teaching English grammar more explicitly and with more of a focus on form. (p.39)

The two approaches have their own strengths and weaknesses; there is no doubt about that. Ideally, these two approaches should not be seen as separate entities, but rather as complementary to each other. A grammar rule presented covertly via a text or communicative activity can be supported by an explicit explanation to enable students to understand the rule. A grammar rule presented overtly or explicitly should be supported by activities which encourage students to use the structures for communicative purposes. Chitravelu et.al. (2005). The main aim of teaching grammar is to help our students use English correctly in all forms of communication. Thus, both approaches can complement each other to bring out the best in our students. Based on the arguments presented above, we should employ the best of both worlds in our education system with some adjustments and changes to suit the Malaysian education system to produce Malaysians who can communicate articulately in the business and diplomatic world without being short changed.

\section{References}

Babic, Z .(2010).Grammar Acquisition Enhancement - A Project. Paper presented at $43^{\text {rd }}$

International Annual IATEFL Conference and Exhibition in Cardiff.

Batsone, R. (1995). Grammar. Oxford: Oxford University Press

Beare,K .(2013). Teaching Grammar in an ESL / EFL Setting, English as Second Language. About.com Guide. Retrieved from http://esl.about.com/cs/teachingtechnique/a/a_teachgrammar.htm [21 April 2013]

Brumfit C.(1984). Communicative Methodology in Language Teaching. Cambridge: CUP

Byrd, P .(1998). NCLRC The Essentials of Language Teaching - Grammar in the foreign Language classroom: Making Principled Choices in Modules for the Professional Preparation of Teaching Assistants in Foreign Languages.http://www.nclrc.org/ Essentials/grammar/grindex.htm

Chitravelu, N et.al. (2005).ELT Methodology: Principles and Practice. $2^{\text {nd }}$ Ed. Shah Alam: Oxford University Press.

Chung,S.F .(2005). A Communicative Approach to Teaching Grammar: Theory and Practice. The English Teacher 34, 33-50. 
Ellis,R .(2006).Current Issues in the Teaching of Grammar: An SLA Perspective. Tesol Quarterly. 40(1), 83-107

Farrel,T et.al (2005). Conceptions of Grammar Teaching: A Case Study of Teachers' Beliefs and Classroom Practices. TESL-EJ. 9(2), 1-13

Fromkin, $\mathrm{V}$ et al .(2011).An Introduction to Language. $9^{\text {th }}$ Ed. Boston:Wadsworth

Gardner,S .(2008).Changing approaches to teaching grammar.ELTED.11, 39-44

Krishnan, G .(2012).ICT and Teachers' Attitude in English Language Teaching. Asian Social Science. 8(11), 8-12

Ha,P.L.et.al .(2013). Nation Building, English as an International Language, Medium of Instruction and Language Debate: Malaysia and Possible ways Forward. Journal of International and Comparative Education

Hymes, D. H. (1972). On Communicative Competence.In Pride, J. B., \& Holmes, J. (Eds.), Sociolinguistics, $269-293$. Baltimore, USA: Penguin Education, Penguin Books Ltd.

Krashen, S. (1985). The Input Hypothesis: Issues and Implications. London:Longman

Mareva,R\&Nyota, S .(2012). Structural or communicative approach: A case study of English Language teaching in Masvingo urban and peri-urban secondary schools. Internal Journal of English and Literature.3(5), 103-111

Pawlak, M .(2004).On the Effectiveness of Options in Grammar Teaching: Translating Theory and Research into Classroom Practice. Studia Anglica Posnaniensia. 40, 269-287

Pienemann, M. (1984). Psychological constraints on the teachability of languages. "Studies in Second Language Acquisition," 6, 186-214.

Schmidt, R. (1990). The role of consciousness in second language learning. Applied Linguistics 11, 17-46

Richards, J.C.\& Rodgers, T.C. (1995).Approaches and Methods in Language Teaching. A description and analysis. Cambridge: CUP.

Richards, J.C., Gallo,P.B. \& Renandya, W.A. (2001).Exploring Teachers' Beliefs and the Processes of Change. PAC Journal 1(1), 41-58. 